\title{
Analysis of Energy and Greenhouse Gas Emissions of Rice Straw to Energy Chain in Egypt
}

\author{
Noha Said, ${ }^{\mathrm{a}}$ Adel Alblawi, ${ }^{\mathrm{b}}$ Ibrahim Hendy, ${ }^{\mathrm{a}}$ and Mahmoud Abdel Daiem ${ }^{\mathrm{a}, \mathrm{c}, *}$ \\ Rice straw as a source of energy could substitute for fossil fuels and \\ reduce greenhouse gas (GHG) emissions. Thus, the aim of this paper was \\ to analyze the energy and GHG emissions of rice straw to the energy chain \\ in Egypt. The analysis was performed starting from paddy production, \\ straw collection and transportation, and energy generation for two \\ scenarios: power plant and anaerobic digestion plant. The results showed \\ that the paddy production and transportation stage represented the \\ highest contribution of the total energy consumption and GHG emissions \\ for the two scenarios, respectively. The energy potential was estimated \\ with $4193 \mathrm{GWh}$ electricity and 25,647 $\times 10^{6} \mathrm{MJ}$ of biogas energy. It was \\ also found that use of rice straw as an energy source could reduce the use \\ of fossil fuel and mitigate air pollution from direct burning of rice straw by \\ $3 \mathrm{Mt} \mathrm{CO}_{2}$-eq of $\mathrm{GHG}$ emissions.
}

Keywords: Rice straw; Energy; GHG emissions; Electricity; Biogas

Contact information: a: Environmental Engineering Department, Faculty of Engineering, Zagazig University, Zagazig, 44519, Egypt; b: Mechanical Engineering Department, College of Engineering, Shaqra University, 11911, Dawadmi, Ar Riyadh, Saudi Arabia; c: Civil Engineering Department, College of Engineering, Shaqra University, 11911, Dawadmi, Ar Riyadh, Saudi Arabia;

*Corresponding author: engdaim@ugr.es

\section{INTRODUCTION}

Widespread and massive consumption of fossil fuels has led to rapid economic growth in advanced industrial societies, but it has also increased carbon dioxide $\left(\mathrm{CO}_{2}\right)$ in the atmosphere and consequently caused global warming and climate change (Bilgen et al. 2008). In consequence, alternative energy sources, such as renewable energies, are an opportunity to replace and/or subsidize fossil fuels and obtain the safest, most costefficient, and most practical energy (Bilgen et al. 2008; Demirbas et al. 2009). Currently, renewable energy supplies $17 \%$ of the world's primary energy, counting traditional biomass that represents $9 \%$, nevertheless, it is projected to double the share of renewable energy in the global final energy consumption by 2030 (Demirbas et al. 2009).

Rice straw as a biomass source is produced in great amounts, and it represents the largest unutilized crop residue in Egypt (Said et al. 2013b). Field burning is the major practice for removing rice straw, but it results in air pollution and consequently affects public health (Sarkar et al. 2012). However, rice straw has a high energy potential and thus can become a source of alternative energy that substitutes fossil energy for reducing GHG emissions as well as avoid the local pollution problems from open burning (Said et al. 2013a, 2014). Today, densified rice straw can be easily handled and transported to recover its energy (Said et al. 2015). Energy from rice straw can be recovered directly in the form of heat through a combustion process, or it can be converted to a valuable energy product 
through indirect techniques such as anaerobic digestion (AD) (Said et al. 2013a; Abdel Daiem et al. 2018; Ahmed et al. 2019).

Some scientific articles have studied the life cycle assessment of rice straw-based power generation and analyzed energy and environmental aspects related to the use of rice straw as an energy source in different countries (Singh et al. 2010; Delivand et al. 2011; Shafie et al. 2013, 2014; Soam et al. 2017). Due to the low number of studies and lack of information about rice straw utilization for energy generation in Egypt, the main objective of this paper was to analyze the energy and GHG emissions of rice straw preparation stages for energy generation in Egypt. The analysis was performed starting from paddy production, straw collection, straw transportation, and energy generation.

\section{EXPERIMENTAL}

\section{Materials}

\section{Data collection}

Data of paddy production and cultivated areas was collected from the Central Agency for Public Mobilization and Statistics (CAPMS 2018). The different rice producer governates in Egypt are Port Said, Damiietta, Dakahliya, Sharkia, Qalyoubia, Kafr Elsheikh, Gharbia, Behera, Ismailia, Beni suef, and Fayoum, as illustrated in Fig. 1. Paddy production, cultivated areas in these governates are indicated in Table 1. As indicated in the table, Dakahlia, Kafr Elsheikh, Sharkia, Behera, and Gharbia are the largest rice cultivation areas. These governates contribute $97.41 \%$ of the Egyptian rice production. The amount of rice straw production was derived according to Shafie et al. (2014), using the value of straw to grain ratio (0.75). As indicated in the table, approximately $97.41 \%$ of the total rice straw production was generated in the six major rice producer governates as mentioned before with respect to paddy production.

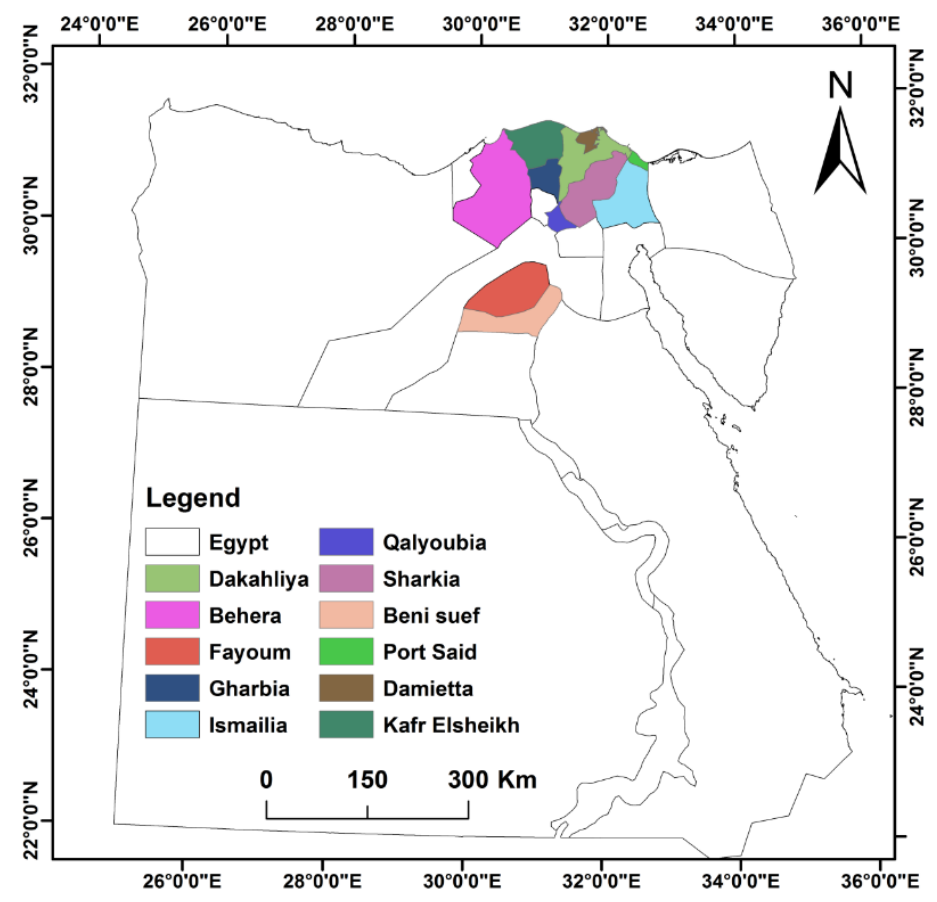

Fig. 1. An overall map of paddy production governates in Egypt 
Table 1. Paddy Production, Cultivated Area, and Straw Production for the Different Governates in Egypt in 2015 (CAPMS 2018)

\begin{tabular}{|c|c|c|c|c|}
\hline Governate & $\begin{array}{c}\text { Paddy } \\
\text { Production (ton) }\end{array}$ & $\begin{array}{c}\text { Cultivated } \\
\text { Area (ha) }\end{array}$ & $\begin{array}{c}\text { Rice Straw } \\
\text { Production (ton) }\end{array}$ & $\begin{array}{c}\text { Total Straw } \\
\text { Production (\%) }\end{array}$ \\
\hline Dakahliya & 1686328.00 & 159877.62 & 1264746.00 & 35.01 \\
\hline Kafr Elsheikh & 953647.00 & 104577.48 & 715235.25 & 19.80 \\
\hline Sharkia & 869009.00 & 92871.24 & 651756.75 & 18.04 \\
\hline Behera & 622582.00 & 68272.68 & 466936.50 & 12.93 \\
\hline Gharbia & 378686.00 & 45572.52 & 284014.50 & 7.86 \\
\hline Damiietta & 181364.00 & 24651.48 & 136023.00 & 3.77 \\
\hline Port Said & 73612.00 & 8833.44 & 55209.00 & 1.53 \\
\hline Qalyoubia & 33816.00 & 3816.96 & 25362.00 & 0.70 \\
\hline Ismailia & 13183.00 & 1538.04 & 9887.25 & 0.27 \\
\hline Beni suef & 2789.00 & 278.88 & 2091.75 & 0.06 \\
\hline Fayoum & 1368.00 & 164.22 & 1026.00 & 0.03 \\
\hline Total & 4816384.00 & 510454.56 & 3612288.00 & 100.00 \\
\hline
\end{tabular}

\section{Methods}

The analysis of straw to energy chain included straw preparation; starting from paddy production, straw collection and transportation, and finally energy generation from two scenarios: power plant and AD plant, as illustrated in Fig. 2. Energy consumption and GHG emissions emitted through those processes were investigated according to inventory data displayed in Table 2. The energy consumption of straw collection included all machinery using baling technique and considered the diesel consumption in machinery (Shafie et al. 2014). Transportation from farm to power plant included two steps, where straw is first transported to the collection center with a tractor trolley, then transported to the power plants with a truck (Bakker 2011; Soam et al. 2017). For the AD process, the transportation was considered from farm to the collection center only where the straw can be directed easily to the plant to produce biogas, therefore, rural people could use the biogas for cooking (Singh et al. 2014; Soam et al. 2017).

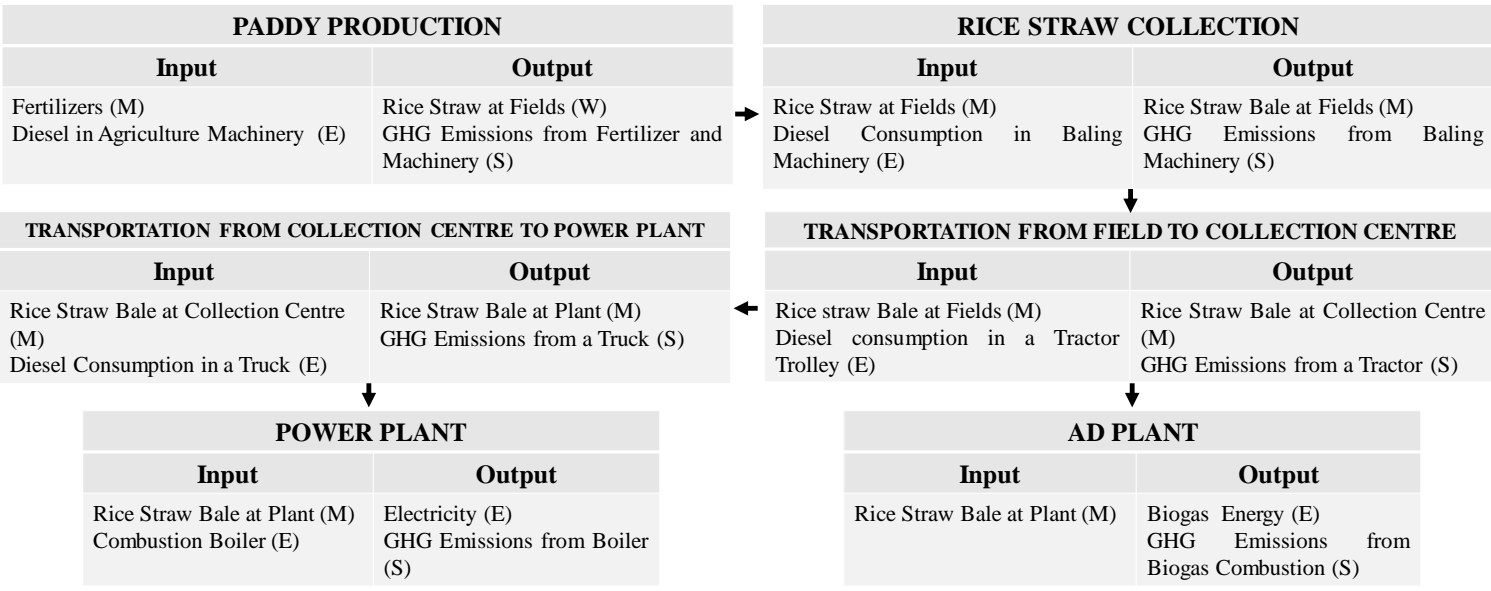

Fig. 2. System boundaries for rice straw-energy generation Note: Material (M), Energy (E), Waste (W), and Emission (S)

The analysis quantified equivalent $\mathrm{CO}_{2}$ emissions of the three primary $\mathrm{GHG}$ : $\mathrm{CO}_{2}$, methane $\left(\mathrm{CH}_{4}\right)$, and nitrous oxide gases (NOx) (Delivand et al. 2011; Shafie et al. 2013). 
The GHG emissions from straw collection were computed considering diesel consumption (Bakker and Poppens 2011). Transport emissions are expressed in grams $\mathrm{CO}_{2}$-eq emitted for every ton moved over one kilometer ( $\mathrm{g} \mathrm{CO}_{2}$-eq per ton. $\left.\mathrm{Km}\right)$, considering loaded and unloaded travel distances in kilometers and rice straw yield in tons (Bakker 2011). Biogenic emissions of $\mathrm{CO}_{2}$ from the power plant were considered zero because the amount of $\mathrm{CO}_{2}$ produced during combustion is utilized during photosynthesis while growing crops (Shafie et al. 2014). However, $\mathrm{CO}_{2}$-eq straw fuel emissions could be estimated respecting $\mathrm{CH}_{4}$ and $\mathrm{NO}_{\mathrm{x}}$ gases according to Delivand et al. (2011), Soam et al. (2017), and Shafie et al. (2014). In contrast, $\mathrm{CO}_{2}$ emissions from biogas combustion are biogenic and hence considered not applicable. Therefore, $\mathrm{CH}_{4}$ and $\mathrm{NO}$ x gases have been taken in consideration (Soam et al. 2017).

Table 2. Inventory Data Used for Energy Consumption and GHG Emission Calculations

\begin{tabular}{|c|c|c|}
\hline Parameter & Value & References \\
\hline $\begin{array}{l}\text { Energy Consumption for Paddy } \\
\text { Production }\end{array}$ & $12225.97 \mathrm{MJ} / \mathrm{ha}$ & Shafie et al. 2014 \\
\hline Energy Unit of Diesel & $38.19 \mathrm{MJ} / \mathrm{L}$ & $\begin{array}{l}\text { El Shimi and } \\
\text { Moustafa } 2018\end{array}$ \\
\hline $\begin{array}{l}\text { Diesel Consumption for Paddy } \\
\text { Production }\end{array}$ & $7.00 \mathrm{~L} / \mathrm{ha}$ & Shafie et al. 2014 \\
\hline Trolley Capacity & 1.50 ton & Soam et al. 2017 \\
\hline Trolley Diesel Consumption (Loaded) & $4.50 \mathrm{Km} / \mathrm{L}$ & Soam et al. 2017 \\
\hline $\begin{array}{c}\text { Trolley Diesel Consumption } \\
\text { (Unloaded) }\end{array}$ & $5.50 \mathrm{Km} / \mathrm{L}$ & Soam et al. 2017 \\
\hline $\begin{array}{l}\text { Truck Capacity } \\
\end{array}$ & 20 Bales & Soam et al. 2017 \\
\hline Truck Diesel Consumption (Loaded) & $5.50 \mathrm{Km} / \mathrm{L}$ & Soam et al. 2017 \\
\hline Truck Diesel Consumption (Unloaded) & $6.50 \mathrm{Km} / \mathrm{L}$ & Soam et al. 2017 \\
\hline Average Mass of Straw Bales & $20.00 \mathrm{Kg}$ & Soam et al. 2017 \\
\hline $\begin{array}{c}\text { Transport Distance from Field to } \\
\text { Collection Center }\end{array}$ & $10.00 \mathrm{Km}$ & $\begin{array}{c}\text { Bakker } 2011 \\
\text { Soam et al. } 2017\end{array}$ \\
\hline $\begin{array}{c}\text { Transport Distance from Collection } \\
\text { Center to Power Plant }\end{array}$ & $50.00 \mathrm{Km}$ & $\begin{array}{l}\text { Bakker } 2011 \\
\text { Soam et al. } 2017\end{array}$ \\
\hline GHG Emissions from Paddy Collection & $1.20 \mathrm{Kg} \mathrm{CO}_{2}$-eq/Kg paddy rice & Farag et al. 2013 \\
\hline GHG Emissions from Straw Collection & $83.80 \mathrm{~g} \mathrm{CO}_{2}-\mathrm{eq} / \mathrm{MJ}$ & $\begin{array}{c}\text { Bakker and } \\
\text { Poppens } 2011\end{array}$ \\
\hline GHG Emissions from Transportation & $221.00 \mathrm{~g} \mathrm{CO}_{2}$-eq/ton.Km & Bakker 2011 \\
\hline GHG Emissions from Boiler & $0.001 \mathrm{Kg}$ of $\left(\mathrm{NOx}+\mathrm{CH}_{4}\right) / \mathrm{kWh}$ & $\begin{array}{l}\text { Soam et al. } 2017 \\
\text { Shafie et al. } 2014\end{array}$ \\
\hline $\begin{array}{l}\text { GHG Emissions from Biogas } \\
\text { Combustion }\end{array}$ & $0.081 \mathrm{~kg}$ of $\left(\mathrm{NO} x+\mathrm{CH}_{4}\right) / \mathrm{GJ}$ & Soam et al. 2017 \\
\hline
\end{tabular}

A power plant uses a combustion boiler with steam turbine for electricity generation. Straw characteristics are critical factors influencing the operation and maintenance of plants (Soam et al. 2017). The straw characteristics were used in determining lower heating value (LHV) in $\mathrm{MJ} / \mathrm{kg}$, which is used in determining electricity output power of straw (E) in KWh. The LHV and E were calculated according to Eq. 1 and 2, respectively (Gadde et al. 2009), where straw characteristics were taken according to Said et al. (2013a) as follows: moisture content (MC, 7.18\%); carbon (C, 39.01\%); hydrogen $(\mathrm{H}, 6.59 \%)$; nitrogen $(\mathrm{N}, 0.64 \%)$; oxygen $(\mathrm{O}, 53.32 \%)$, and sulfur $(\mathrm{S}, 0.009 \%)$. The estimate LHV is $13.82 \mathrm{MJ} / \mathrm{Kg}, W$ is the amount of straw in ton and the conversion 
efficiency of the plant (CE) was taken as approximately 30\%. Equations 1 and 2 are as follows:

$$
\begin{aligned}
& L H V=34.8 C+93.9 H+10.5 S+6.3 N-10.8 O-2.5 M C \\
& E=W x L H V x C E
\end{aligned}
$$

In the $\mathrm{AD}$ process, the plant consists of one stage operating at 30 to $40{ }^{\circ} \mathrm{C}$, where straw is mixed with water and cattle dung to reach desired solid content of $10 \%$. The biogas system was assumed to be a fixed dome, $2 \mathrm{~m}^{3}$ household type, and the process operated in continuous feeding mode for 350 days/year operating cycle, and with 10 years of operational life (Singh et al. 2014; Soam et al. 2017). The energy production from the AD plant was estimated according to Börjesson and Berglund (2007) and Soam et al. (2017), where one ton of rice straw produces $7.1 \mathrm{GJ}$ energy from biogas.

\section{RESULTS AND DISCUSSION}

Energy consumption of paddy production and straw collection for the six major governates and other governates are illustrated in Table 3. The Dakahliya governate had the highest energy consumption for both paddy production and straw collection, accounting for $31.3 \%$ of total energy consumption. Meanwhile, energy consumption of paddy production was higher than straw collection due to the high energy consumed in the farming stages due to the consumption of fertilizer and agriculture machinery activities (Farag et al. 2013). Kafr Elsheikh recorded the second governate for energy consumption followed by Sharkia, representing $20.5 \%$ and $18.2 \%$ of the total, respectively. The annual total energy consumption for all governates reached to $6,241 \times 10^{6} \mathrm{MJ}$ and $137 \times 10^{6} \mathrm{MJ}$ for paddy production and straw collection, respectively. The energy consumption of paddy production and straw collection for one kg of rice straw are $1.73 \mathrm{MJ}$ and $0.038 \mathrm{MJ}$, which are lower than 2.52 MJ and 0.11 MJ estimated by Shafie et al. (2014), respectively.

Table 3. Energy Consumption ( $\left.10^{6} \mathrm{MJ}\right)$ for the Different Governates at Different Stages

\begin{tabular}{|c|c|c|c|c|}
\hline Governate & Paddy Production & Straw Collection & \multicolumn{2}{|c|}{ Transportation } \\
\cline { 3 - 5 } & & & Power Plant & AD Plant \\
\hline Dakahliya & 1954.66 & 42.74 & 2026.21 & 129.45 \\
\hline Kafr Elsheikh & 1278.56 & 27.96 & 1145.86 & 73.20 \\
\hline Sharkia & 1135.44 & 24.83 & 1044.16 & 66.71 \\
\hline Behera & 834.70 & 18.25 & 748.07 & 47.79 \\
\hline Gharbia & 557.17 & 12.18 & 455.01 & 29.07 \\
\hline Damiietta & 301.39 & 6.59 & 217.92 & 13.92 \\
\hline Others & 178.88 & 3.91 & 149.92 & 9.58 \\
\hline Total & 6240.80 & 136.46 & 5787.14 & 369.71 \\
\hline
\end{tabular}

Transportation energy for the energy consumption-based power plant was higher than $\mathrm{AD}$ due to the high transportation distance. The highest transportation energy consumption was found in Dakahliya, as it had the highest straw yield. Transportation energy for the energy consumption-based power plant and AD plant is indicated in Table 3. As demonstrated in the table, transportation energy consumption-based power plant for Dakahliya accounted to $2026.21 \times 10^{6} \mathrm{MJ} /$ year, while its value was $129.45 \times 10^{6} \mathrm{MJ} /$ year 
for the AD-base plant. Dakahliya, Kafr Elsheikh, Sharkia, Behera, Gharbia, and Damietta accounted approximately $35.01 \%, 19.80 \%, 18.04 \%, 12.93 \%, 7.86 \%$, and $2.59 \%$ of the total, respectively. The annual total transportation energy of the consumption-based power plant and $\mathrm{AD}$ plant reached to approximately $5,788 \times 10^{6} \mathrm{MJ}$ and $370 \times 10^{6} \mathrm{MJ}$, respectively.

Considering all stages of rice straw preparation, the total energy consumptionbased power plant and $\mathrm{AD}$ accounted to $12,160 \times 10^{6} \mathrm{MJ} /$ year and $6,750 \times 10^{6} \mathrm{MJ} / \mathrm{year}$, respectively. For the power plant, the highest contribution to the total energy consumption was from paddy production (51.3\%), followed by transportation (47.6\%), and straw collection $(1.12 \%)$. In case of $\mathrm{AD}$, the transportation energy consumption represented only $5.48 \%$ of the total followed by straw collection $(2.02 \%)$ and the highest energy consumption was from paddy production $(92.5 \%)$. The high energy consumption in paddy production stage can be attributed to the high energy consumed in farming stages due to consumption of fertilizers and agriculture machinery use as found and described by Shafie et al. (2014).

Energy production from rice straw for the different governates power plants and AD plant is illustrated in Fig. 3a and b, respectively. As indicated in the figure, Dakahliya had the maximum annual energy production, accounting for $35.0 \%$ of the total energy production. The annual electricity output from rice straw fuel-based power plant in Dakahliya was 1,468 GWh, while energy from biogas generated from AD plant was 8,980 $\times 10^{6} \mathrm{MJ}$. The annual total energy obtained for all governates was 4,193 GWh electricity and $25650 \times 10^{6} \mathrm{MJ}$ of biogas energy for straw fuel-based power plant and AD plant, respectively. Thus, the electricity production from one ton of rice straw was $1165 \mathrm{KWh}$, which was higher than $938 \mathrm{KWh}$ found by Shafie et al. (2014) and lower than $1367 \mathrm{KWh}$ estimated by Soam et al. (2017). The variation in energy obtained by these studies may be attributed to the different characteristics of the used rice straw and according to the power plant efficiency (Soam et al. 2017).

The GHG emissions of rice straw-based energy generation begins with paddy production and continues to energy generation. The $\mathrm{CO}_{2}$ gases represent a high percentage of GHG emissions (Shafie et al. 2014). Only as an exception, the paddy production process has a great advantage in relation to the global warming impact, due to the absorption of carbon through photosynthesis (Abdelhady et al. 2014; Shafie et al. 2014). Table 4 shows GHG emissions $\left(\mathrm{CO}_{2}-\mathrm{eq}\right)$ for paddy production and straw collection. As shown in the table, the highest annual GHG emissions emitted from paddy production and straw collection were found in Dakahliya with values of 2,050 t $\mathrm{CO}_{2}$-eq and 3,582 $\mathrm{t} \mathrm{CO}_{2}$-eq, accounting for $35.0 \%$ and $31.3 \%$ of the total, respectively. Meanwhile, the total GHG emissions emitted from paddy production and straw collection for all governates were 5,857 $\mathrm{t} \mathrm{CO}_{2}$-eq/ year and 11,435 $\mathrm{t} \mathrm{CO}_{2}$-eq/year, respectively. The obtained $\mathrm{CO}_{2}$-eq from straw collection was approximately $0.003 \mathrm{Kg} \mathrm{CO} 2-\mathrm{eq} / \mathrm{Kg}$ straw, which is lower than $0.012 \mathrm{Kg} \mathrm{CO}_{2}-\mathrm{eq} / \mathrm{Kg}$ straw calculated by Bakker and Poppens (2011). Furthermore, The GHG emissions from both paddy production and straw collection were equivalent to $0.01 \mathrm{Kg} \mathrm{CO}_{2}$-eq/ $\mathrm{Kg}$ straw, which is lower than $0.10 \mathrm{Kg} \mathrm{CO}_{2}-\mathrm{eq} / \mathrm{Kg}$ straw estimated by Shafie et al. (2014). The difference in emissions is likely due to differences between studies in farming location, type, allocation method, energy, and emission coefficients (Miller and Kumar 2013). 


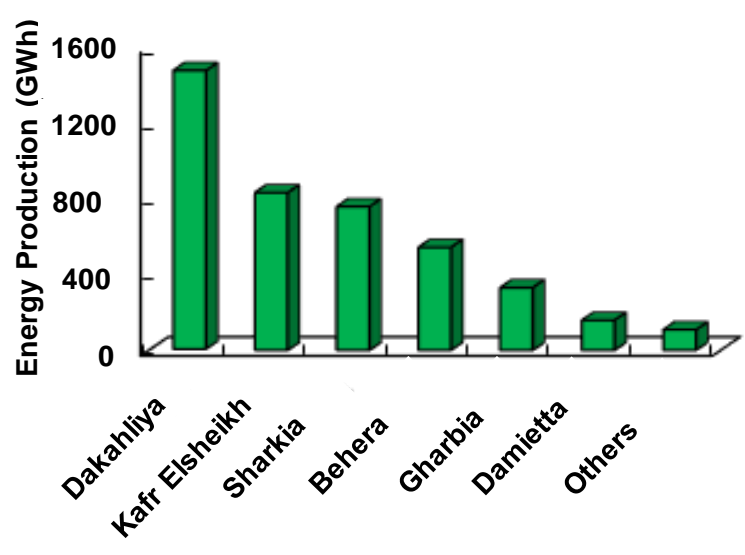

a)

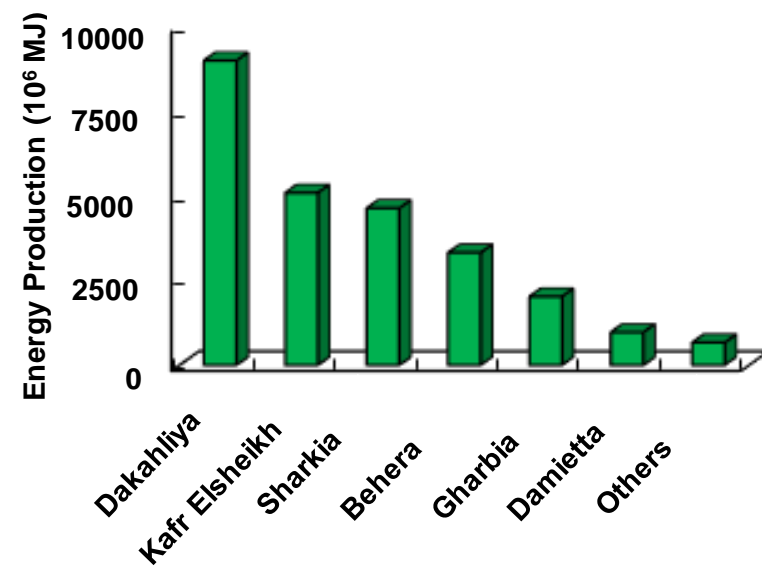

b)

Fig. 3. Energy production for the different governates from rice straw-based a) power plant and b) AD plant

Table 4. GHG Emission (t $\mathrm{CO}_{2}$-eq) for the Different Governates at Different Stages

\begin{tabular}{|c|c|c|c|c|}
\hline Governate & Paddy Production & Straw Collection & \multicolumn{2}{|c|}{ Transportation } \\
\cline { 3 - 5 } & & & Power Plant & AD Plant \\
\hline Dakahliya & 2050.57 & 3581.62 & 33541.06 & 5590.18 \\
\hline Kafr Elsheikh & 1159.63 & 2342.77 & 18968.04 & 3161.34 \\
\hline Sharkia & 1056.71 & 2080.53 & 17284.59 & 2880.76 \\
\hline Behera & 757.06 & 1529.46 & 12383.16 & 2063.86 \\
\hline Gharbia & 460.48 & 1020.93 & 7532.06 & 1255.34 \\
\hline Damiietta & 220.54 & 552.25 & 3607.33 & 601.22 \\
\hline Others & 151.72 & 327.78 & 2481.64 & 413.61 \\
\hline Total & 5856.73 & 11435.33 & 95797.88 & 15966.32 \\
\hline
\end{tabular}

Transportation distances play a major role in GHG emissions. Increases in the transportation distance from the collection center to power plant contribute to increased GHG emissions, as detected by Shafie et al. (2014). Table 4 includes GHG emissions emitted from the transportation of rice straw fuel-based power plant and AD plant, respectively. As can be seen in the table, a remarkable increase in emissions emitted from transportation to power plant comparing AD plant was detected, as found by Soam et al. (2017). Dakahliya as the highest governate in GHG emissions emitted from transportation, has annual values of approximately 33,540 t $\mathrm{CO}_{2}$-eq and 5,590 $\mathrm{t} \mathrm{CO}_{2}$-eq for the power plant and AD plant, respectively. Meanwhile, the annual total GHG emissions emitted from transportation to power plant and $\mathrm{AD}$ plant for all governates were 95,800 $\mathrm{t} \mathrm{CO}_{2}$-eq and $15,970 \mathrm{t} \mathrm{CO}_{2}$-eq, respectively.

The GHG emitted from plants includes emissions from the combustion boiler of the rice straw power plant and combustion of biogas generated from the AD process. As mentioned before, $\mathrm{CO}_{2}$ emissions from the straw-based power plant and biogas combustion are biogenic and considered zero; therefore, GHG emissions included $\mathrm{CH}_{4}$ and $\mathrm{NOx}$ gases. Figure 4 illustrates the GHG emissions generated according to boiler and biogas combustion. As indicated in Fig. 4, GHG emission was higher for the combustion boiler compared to biogas combustion, similar to Soam et al. (2016). This indicated that the straw fuel-based $\mathrm{AD}$ process has more environmental benefits than the power plant (Soam et al. 
2016). The annual GHG emitted in Dakahliya, as the greatest values among different governates, reached to $1,468 \mathrm{t} \mathrm{CO}_{2}$-eq and $727 \mathrm{t} \mathrm{CO}_{2}$-eq from the power plant and $\mathrm{AD}$ plant, respectively. Meanwhile, the total GHG emissions emitted from the combustion boiler of the rice straw power plant and combustion of biogas generated from the AD process for all governates accounted to 4,190 t CO 2 -eq/year and 2,080 t $\mathrm{CO}_{2}$-eq/year, respectively. The difference in emissions for the two plants arises due to different processing technologies and the displaced product (Soam et al. 2016).

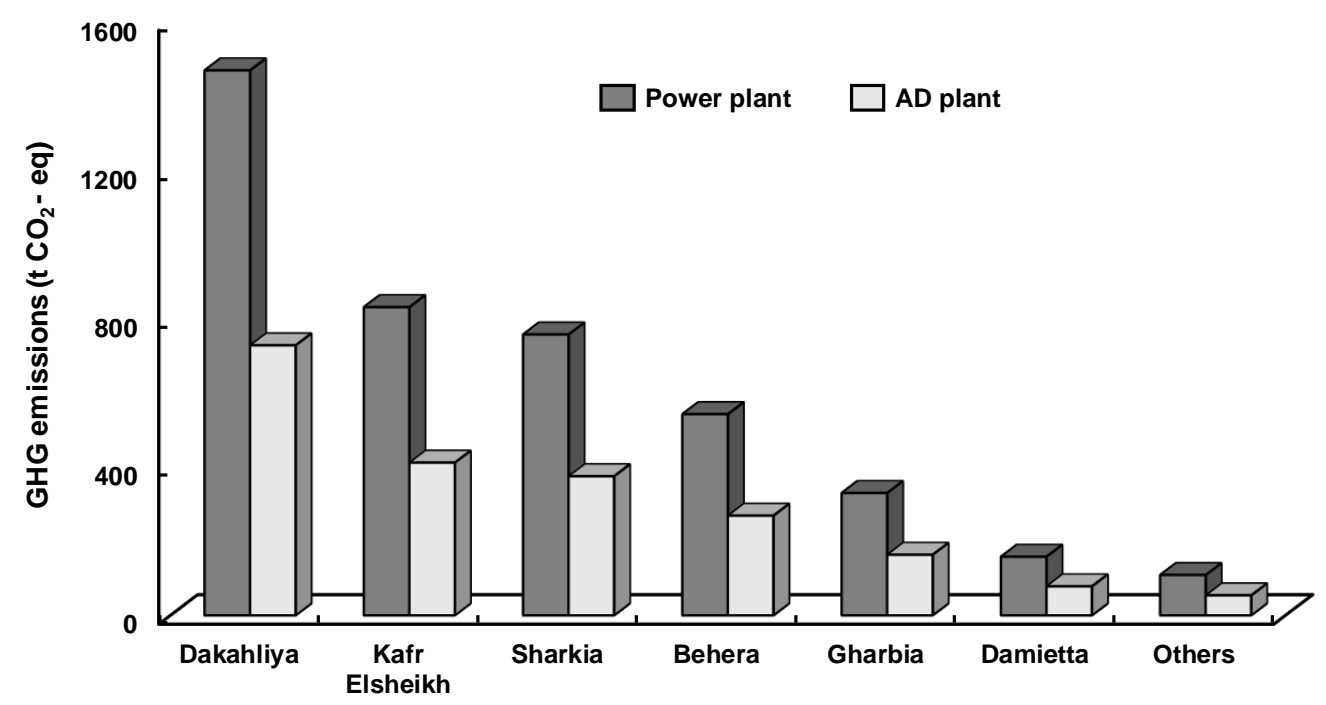

Fig. 4. GHG emissions from energy generation processes

Based on the results of the current study, the total annual GHG emissions generated from rice straw-based power plant are 117,280 $\mathrm{t} \mathrm{CO}_{2}$-eq, which are higher than $35,340 \mathrm{t} \mathrm{CO}_{2}$-eq from the $\mathrm{AD}$ plant. Figures $5 \mathrm{a}$ and $\mathrm{b}$ indicate the GHG emission contribution of the different stages for rice straw fuel-based power plant and the AD plant. For the power plant, transportation had the highest emissions, accounting for $81.7 \%$ of the total emissions, followed by straw collection and paddy production. Similar results were found by Soam et al. (2017) and Shafie et al. (2014), where they found that the highest contribution to the total GHG emissions was from straw transportation with $92 \%$ and $57.5 \%$, respectively. Meanwhile, combustion boilers of the power plant had the lowest emissions among the different stages. Although transportation emission represented the highest contribution among the different stages-based AD plant, its contribution percentage $(45.2 \%)$ was lower than that $(81.7 \%)$ from the power plant. For the straw fuel-based AD, the second highest contribution was for straw collection followed by paddy production, while biogas combustion emission had the lowest percentage $(5.88 \%)$, as can be seen in the figure.

According to the obtained results, the annual air pollution of $3.2 \mathrm{Mt} \mathrm{CO}_{2}$-eq from the direct burning of rice straw (Farag et al. 2013) could be mitigated by using rice straw for electricity generation and biogas energy source to $0.12 \mathrm{Mt} \mathrm{CO}_{2}$-eq and $0.035 \mathrm{Mt} \mathrm{CO}_{2}$ eq, respectively. Therefore, it is expected to have a $\mathrm{GHG}$ emission reduction of approximately $3 \mathrm{Mt} \mathrm{CO}_{2}$-eq per annual country emissions from non-open field burning and using rice straw as an energy source. This reduction represents approximately $0.94 \%$ reduction of the total annual country's GHG emissions (Nakhla et al. 2013). Similar results were found by Delivand et al. (2011) who expected to have a GHG emission reduction of 
approximately 2 to $3.5 \mathrm{Mt}$ per year, which is equivalent to approximately 1 to $1.13 \%$ reduction to the total annual Thailand's GHG emissions. Additionally, Shafie et al. (2014) found that the power generation of rice straw, if applied, can reduce the GHG emission up to $1 \%$ of total GHG emissions in Malaysia. These small percentages of reduction will become more attractive in the future as these countries strive to reduce their carbon emissions. According to Delivand et al. (2011), 0.368 t CO $2-e q / t$ dry straw and $0.683 \mathrm{t}$ $\mathrm{CO}_{2}$-eq/t dry straw could be avoided if straw is used instead of natural gas or coal fuel in the power generation sectors. In consequence, $1.24 \mathrm{Mt} \mathrm{CO}_{2}$-eq and 2.29 $\mathrm{Mt} \mathrm{CO}_{2}$-eq could be mitigated annually by substituting the natural gas and coal fuels with rice straw for power generation, respectively. Moreover, $152 \mathrm{~m}^{3}$ natural gas $/ \mathrm{t}$ dry straw or $0.285 \mathrm{t} \mathrm{coal} / \mathrm{t}$ dry straw could be saved (Delivand et al. 2011). As a result, an annual amount of $510 \times$ $10^{6} \mathrm{~m}^{3}$ natural gas and 957,400 $\mathrm{t}$ coal could be saved. Based on the country, fossil fuel consumption for electricity generation of 230 ton of oil equivalent (toe)/GWh (Abdelhady et al. 2014), the straw fuel power plant could be able to reduce the use of fossil fuel by an amount of 964,400 t/year. Thus, the utilization of rice straw for energy generation not only removes the rice straw from field without open burning, but also saves GHG emissions that can contribute to climate change, acidification, and eutrophication, among other environmental problems, as well as it would contribute to savings on the fossil fuel consumptions (Delivand et al. 2011; Shafie et al. 2014).

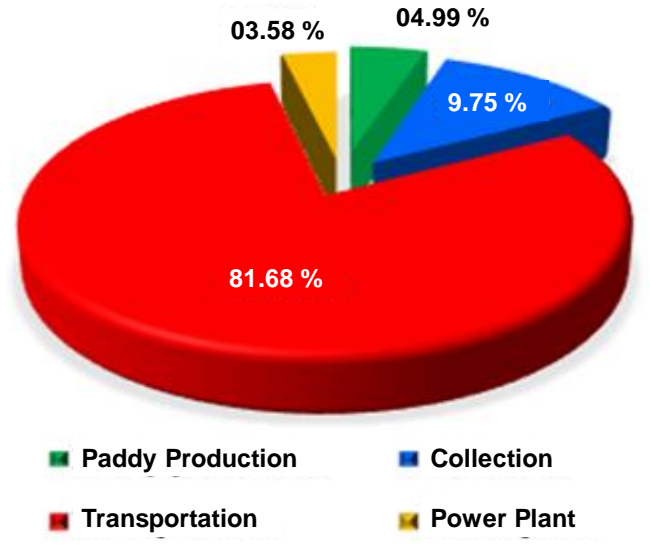

a)

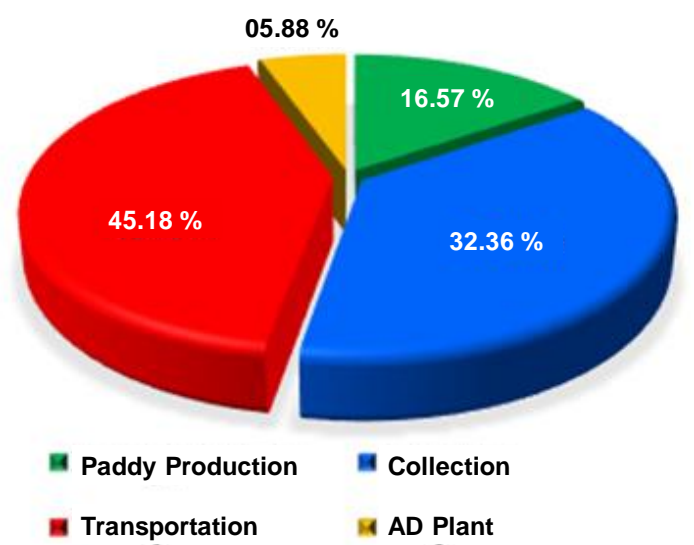

b)

Fig. 5. GHG contribution of the different stages to the total emissions of rice straw fuel-based a) power plant and b) AD plant

\section{CONCLUSIONS}

1. The paddy production and transportation stage represented the highest contribution of the total energy consumption and greenhouse gas (GHG) emissions, respectively.

2. The annual total energy obtained amounted to $4193 \mathrm{GWh}$ electricity and 25,650 $\times 10^{6}$ MJ of biogas energy from straw fuel-based power plant and AD plant, respectively.

3. Air pollution from direct burning of rice straw could be mitigated by $3 \mathrm{Mt} \mathrm{CO}_{2}$-eq of GHG emissions by using rice straw as an energy source. 


\section{ACKNOWLEDGMENTS}

The authors are grateful to the teamwork at the Environmental Engineering Department in Zagazig University in Egypt for their valuable suggestions and to Shaqra University for its financial supporting through Research Support Program.

\section{REFERENCES CITED}

Abdel Daiem, M. M., Said, N., and Negm, A. M. (2018). "Potential energy from residual biomass of rice straw and sewage sludge in Egypt," Procedia Manufacturing 22, 818825. DOI: 10.1016/j.promfg.2018.03.116

Abdelhady, S., Borello, D., Shaban, A., and Rispoli, F. (2014). "Viability study of biomass power plant fired with rice straw in Egypt," Energy Procedia 61, 211-215. DOI: 10.1016/j.egypro.2014.11.1072

Ahmed, D., Wagdy, R., and Said, N. (2019). "Evaluation of biogas production from anaerobic co-digestion of sewage sludge with microalgae and agriculture wastes," BioResources 14(4), 8405-8412. DOI: 10.15376/biores.14.4.8405-8412

Bakker, A. B. (2011). "An evidence-based model of work engagement," Current Directions in Psychological Science 20(4), 265-269. DOI: 10.1177/0963721411414534

Bilgen, S., Keleş, S., Kaygusuz, A., Sarı, A., and Kaygusuz, K. (2008). "Global warming and renewable energy sources for sustainable development: A case study in Turkey," Renewable and Sustainable Energy Review 12(2), 372-396. DOI: 10.1016/j.rser.2006.07.016

Börjesson, P., and Berglund, M. (2007). "Environmental systems analysis of biogas systems - Part II: The environmental impact of replacing various reference systems," Biomass and Bioenergy 31(5), 326-344. DOI: 10.1016/j.biombioe.2007.01.004

Central Agency for Public Mobilization and Statistics (CAPMS) (2018). "Total quantity of fish production," CAPMAS, (https://www.capmas.gov.eg/Pages/IndicatorsPage.aspx?page_id=6151\&ind_id=26), Accessed 1 Dec 2018.

Delivand, M. K., Barz, M., and Garivait, S. (2011). "Overall analyses of using rice straw residues for power generation in Thailand-project feasibility and environmental GHG impacts assessment," Journal of Sustainable Energy \& Environment Special Issue 2011, 39-46.

Demirbas, M. F., Balat, M., and Balat, H. (2009). "Potential contribution of biomass to the sustainable energy development," Energy Conversion and Management 50(7), 1746-1760. DOI: 10.1016/j.enconman.2009.03.013

El Shimi, H. I., and Moustafa, S. S. (2018). "Biodiesel production from microalgae grown on domestic wastewater: Feasibility and Egyptian case study," Renewable and Sustainable Energy Reviews 82, 4238-4244. DOI: 10.1016/j.rser.2017.05.073

Farag, A. A., Radwan, H. A., Abdrabbo, M. A. A., Heggi, M. A. M., and McCarl, B. A. (2013). "Carbon footprint for paddy rice production in Egypt," Nature and Science 11(12), 36-45.

Gadde, B., Menke, C., and Wassmann, R. (2009). "Rice straw as a renewable energy source in India, Thailand, and the Philippines: Overall potential and limitations for 
energy contribution and greenhouse gas mitigation," Biomass and Bioenergy 33(11), 1532-1546. DOI: 10.1016/j.biombioe.2009.07.018

Miller, P., and Kumar, A. (2013). "Development of emission parameters and net energy ratio for renewable diesel from Canola and Camelina," Energy 58(1), 426-437. DOI: 10.1016/j.energy.2013.05.027

Nakhla, D. A., Hassan, M. G., and Haggar, S. (2013). "Impact of biomass in Egypt on climate change," Nature and Science 5(6), 678-684. DOI: 10.4236/ns.2013.56083

Said, N., Abdel Daiem, M. M., García-Maraver, A., and Zamorano, M. (2014). "Reduction of ash sintering precursor components in rice straw by water washing," BioResources 9(4), 6756-6764. DOI: 10.15376/biores.9.4.6756-6764

Said, N., Abdel Daiem, M. M., García-Maraver, A., and Zamorano, M. (2015). "Influence of densification parameters on quality properties of rice straw pellets," Fuel Processing Technology 138, 56-64. DOI: 10.1016/j.fuproc.2015.05.011

Said, N., Bishara, T., García-Maraver, A., and Zamorano, M. (2013a). "Effect of water washing on the thermal behavior of rice straw," Waste Management 33(11), 22502256. DOI: 10.1016/j.wasman.2013.07.019

Said, N., El-Shatoury, S. A., Díaz, L. F., and Zamorano, M. (2013b). "Quantitative appraisal of biomass resources and their energy potential in Egypt," Renewable and Sustainable Energy Reviews 24, 84-91. DOI: 10.1016/j.rser.2013.03.014

Sarkar, N., Ghosh, S. K., Bannerjee, S., and Aikat, K. (2012). "Bioethanol production from agricultural wastes: An overview," Renewable Energy 37(1), 19-27. DOI: 10.1016/j.renene.2011.06.045

Shafie, S. M., Mahlia, T. M. I., and Masjuki, H. H. (2013). "Life cycle assessment of rice straw co-firing with coal power generation in Malaysia," Energy 57, 284-294. DOI: 10.1016/j.energy.2013.06.002

Shafie, S. M., Masjuki, H. H., and Mahlia, T. M. I. (2014). "Life cycle assessment of rice straw-based power generation in Malaysia," Energy 70, 401-410. DOI: 10.1016/j.energy.2014.04.014

Singh, A., Pant, D., Korres, N. E., Nizami, A., Prasad, S., and Murphy, J. D. (2010). "Key issues in life cycle assessment of ethanol production from lignocellulosic biomass: Challenges and perspectives," Bioresource Technology 101(13), 5003-5012. DOI: 10.1016/j.biortech.2009.11.062

Singh, P., Gundimeda, H., and Stucki, M. (2014). "Environmental footprint of cooking fuels: A life cycle assessment of ten fuel sources used in Indian households," International Journal of Life Cycle Assessment 19(5), 1036-1048. DOI: 10.1007/s11367-014-0699-0

Soam, S., Borjesson, P., Sharma, P. K., Gupta, R. P., Tuli, D. K., and Kumar, R. (2017). "Life cycle assessment of rice straw utilization practices in India," Bioresource Technology 228, 89-98. DOI: 10.1016/j.biortech.2016.12.082

Soam, S., Kapoor, M., Kumar, R., Borjesson, P., Gupta, R. P., and Tuli, D. K. (2016). "Global warming potential and energy analysis of second-generation ethanol production from rice straw in India," Applied Energy 184, 353-364. DOI: 10.1016/j.apenergy.2016.10.034

Article submitted: October 23, 2019; Peer review completed: December 31, 2019; Revised version received and accepted: January 8, 2020; Published: January 13, 2020.

DOI: $10.15376 /$ biores. 15.1.1510-1520 